\title{
25. STRATIGRAPHY OF THE EOCENE CHALKS RECOVERED FROM THE NEW JERSEY MARGIN, LEG 150: SYNTHESIS ${ }^{1}$
}

\author{
Marie-Pierre Aubry, ${ }^{2}$ Scott W. Snyder, ${ }^{3}$ Mickey C. Van Fossen ${ }^{4}$ Michael Urbat,${ }^{5}$ Kenneth G. Miller ${ }^{4}$ Cecilia M.G. McHugh ${ }^{6}$
}

\begin{abstract}
Eocene chalks were recovered from four holes drilled on the slope of the New Jersey continental margin. Calcareous nannofossils provide the main biostratigraphic control, supported by planktonic foraminifers. The chalks are very weakly magnetized, so no magnetostratigraphy could be derived for these sections. Two main unconformities are recognized; one near the lower/middle Eocene boundary and the other within the middle Eocene. It is not possible to determine the age of the surfaces associated with these unconformities because of the lack of magnetostratigraphy and because planktonic foraminiferal biozonal boundaries could not be firmly delineated (due to poor preservation and pervasive reworking). The only datable surface is the youngest Eocene surface at the upper Eocene/Oligocene unconformable contact, which is estimated to be $\sim 34.25 \mathrm{Ma}$.
\end{abstract}

\section{INTRODUCTION}

The documentation of the Eocene stratigraphic record of the New Jersey Margin was one of the secondary objectives of Ocean Drilling Program (ODP) Leg 150, a leg whose main objective as part of the New Jersey Sea-Level Transect was to document the record of Oligocene to Holocene glacioeustasy on the margin (Miller and Mountain, 1994). Eocene chalks were recovered from four of the five Leg 150 drill sites. However, because of uneven penetration, these sites yield little information with regard to the architecture of the Eocene stratigraphic record of the New Jersey Margin and a stratigraphic synthesis from these four sites alone is beyond reach.

We summarize below the stratigraphic subdivision of each Eocene section and the difficulties encountered in establishing magnetostratigraphy and planktonic microfossil stratigraphy for them. Further information may be obtained from individual papers on magnetostratigraphy (Van Fossen and Urbat, this volume), planktonic foraminiferal stratigraphy (Snyder et al., this volume), calcareous nannofossil stratigraphy (Aubry, this volume), and from the description of Sites 902, 903, 904, and 906 by the Shipboard Scientific Party in Mountain, Miller, Blum, et al. (1994).

\section{THE EOCENE SECTIONS: DESCRIPTION}

Eocene clayey chalks were recovered from four of the five sites drilled during Leg 150. A 59.2-m-thick section and a 38.6-m-thick section of upper Eocene chalks were drilled in Holes 902D and 906A

'Mountain, G.S., Miller, K.G., Blum, P., Poag, C.W., and Twichell, D.C. (Eds.), 1996. Proc. ODP, Sci. Results, 150: College Station, TX (Ocean Drilling Program).

${ }^{2}$ Laboratoire de Géologie du Quaternaire, CNRS-Luminy, 13288 Marseille Cedex 09, France. (Current address: Institut des Sciences de l'Evolution, Université Montpellier II, Place Eugène Bataillon, 37095 Montpellier Cedex 05, France.) aubry@isem.univ-montp2.fr

${ }^{3}$ Department of Geology, East Carolina University, Greenville, NC 27858, U.S.A.

${ }^{4}$ Department of Geological Sciences, Rutgers University, Piscataway, NJ 08855 , U.S.A.

${ }_{5}^{5}$ Geologisches Institut, Universität zu Köln, Zülpicherstrasse 49, $5000 \mathrm{Köln}$, Federal Republic of Germany.

'Department of Geology, Queens College, City University of New York, 65-30 Kissena Boulevard, Flushing, NY 11367, U.S.A.
(Shipboard Scientific Party, 1994a, 1994d), respectively. Upper and upper middle Eocene chalks, $85.6 \mathrm{~m}$ thick, were penetrated in Hole 903C (Shipboard Scientific Party, 1994b). Hole 904A is the only hole that provided a substantial Eocene section. It is $246.70 \mathrm{~m}$ thick and extends from upper Eocene to lower middle Eocene (Shipboard Scientific Party, 1994c). Recovery was excellent in Holes 903C and 904A, except in the lower three cores of Hole 904A. Recovery was moderate in Hole 902D and poor in Hole 906A.

The Eocene chalks constitute a single lithologic unit, Unit VII. They consist of semi-indurated, moderately to intensely bioturbated, silica-rich nannofossil chalks with clay and foraminifers. A pronounced clay enrichment close to the upper/middle Eocene contact was observed in Hole 904A. These chalks were deposited in upper bathyal (Hole 903C), middle bathyal (Holes 902D, 906A), and lower bathyal (Hole 904A) settings (Katz and Miller, this volume). In Hole $904 \mathrm{~A}$, a distinct 80 -cm-thick microtektite-bearing interval was recovered, similar to that recovered from Deep Sea Drilling Project (DSDP) Hole 612 (Shipboard Scientific Party, 1987; Poag and Aubry, 1995). It is described in McHugh et al. (this volume). Microtektites were not recovered from Hole $903 \mathrm{C}$, but a siliciclastic lithologic sequence was recovered between 1109.3 and 1109.9 meters below seafloor (mbsf) that is very similar to the microtektite-bearing sequence in Hole 904A, and both levels are thought to reflect the same impact event as that at Site 612 (see Shipboard Scientific Party, 1994c).

In the four holes, the Eocene chalks unconformably overly upper Oligocene silty clays and silty claystones (Unit VI). The contact is sharp in Holes 902D and 904A. The contact was not observed in Hole 903C, where it occurs between two cores, and was not recovered in Hole 906A. This unconformable contact correlates with Seismic Horizon $\mathrm{Ol}$ (Mountain et al., this volume).

\section{STRATIGRAPHY OF THE EOCENE CHALKS Magnetostratigraphy}

Magnetostratigraphy has become a routinely used stratigraphic means that, together with biostratigraphy, helps increase the temporal resolution of stratigraphic sections. Unfortunately, no magnetostratigraphic record was derived at the Leg 150 sites for the Eocene chalks, which were very weakly magnetized. The only interval of some thickness with a magnetic signature is from Hole 904A, where a 
thick, normal-polarity interval characterizes the bulk of the upper Eocene chalks. Yet, as will be discussed below, this normal-polarity interval probably does not correspond to any magnetic chron, but rather reflects residual overprint.

\section{Planktonic Foraminifer Stratigraphy}

It cannot be emphasized enough that the stratigraphic subdivision of the Eocene chalks based on planktonic foraminifers was greatly impaired by (1) poor preservation, (2) pervasive reworking, and (3) absence of the marker species. Planktonic foraminifers are poorly preserved in the upper Eocene chalks. They become erratic in the middle middle Eocene chalks below 490.6 mbsf in Hole 904A, and preservation worsens below 529.8 mbsf in the porcellanitic chalks. The pervasive reworking of middle Eocene foraminiferal tests into the upper Eocene chalks, particularly in Hole 904A around the tektite-bearing interval, prevents the delineation of discrete successive middle Eocene planktonic foraminiferal events, and hence assessment of stratigraphic continuity.

More importantly, most of the marker species in the tropical planktonic zonation of Berggren and Miller (1988) used in Snyder et al. (this volume) are absent, which results in the approximate delineation of zonal boundaries based on secondary markers. Only two biozonal boundaries are delineated based on the zonal criteria in Hole 904A: the P11/P12 zonal boundary is recognized by the highest occurrence (HO) of Morozovella aragonensis in Sample 150-904A$50 \mathrm{X}-4,40-42 \mathrm{~cm}$, and the P14/P15 zonal boundary by the lowest occurrence (LO) of Porticulosphaera semiinvoluta in Sample 150$904 \mathrm{~A}-45 \mathrm{X}-5,40-42 \mathrm{~cm}$. The thicknesses of all other zones in this hole and in Hole $903 \mathrm{C}$ are based on the ranges of secondary markers and are thus approximate. It should be noted that the species used to delineate zonal boundaries differ between Holes $903 \mathrm{C}$ and 904A, and this difference impairs the reliability of correlation between the two holes, based on planktonic foraminifers.

All of this makes it almost impossible to numerically date any horizon in the Eocene chalks based on age estimates of the first appearance (FAD) and last appearance (LAD) datums of planktonic foraminiferal species. The only exception is the dating of the youngest chalk at the level of the Eocene/Oligocene contact, and thereby the determination of the maximum age of the seismic surface $\mathrm{O} 1$ as expressed on the slope part of the New Jersey transect (see below).

\section{Calcareous Nannofossil Stratigraphy}

Calcareous nannofossils constitute the primary means for stratigraphic subdivision of the Eocene chalks recovered during Leg 150. Unlike the foraminiferal stratigraphy, reworking does not impair biozonal subdivision. However, just as for the planktonic foraminifers, poor preservation (mostly dissolution) plagues the calcareous nannofossil record, and assemblages are considerably impoverished in the greater part of Eocene interval. High-density sampling (every 10-50 $\mathrm{cm}$ ) alleviated difficulties in delineating zonal boundaries resulting from poor preservation but it prevented the establishment of a reliable succession of middle Eocene biostratigraphic events (e.g., HOs of Sphenolithus obtusus, Pseudotriquetrorabdulus carinatus, Cruciplacolithus delus, and Chiasmolithus grandis in Zone NP17 [see Aubry, 1992] in Hole 903C) other than those that define zonal boundaries. As a consequence, it is difficult to assess the stratigraphic completeness of the sections. The only interval that cannot be satisfactorily subdivided is the upper NP15-lower NP16 zonal interval. This is not specific to these holes but is a commonly encountered problem because of the scarcity of Blackites gladius. The occurrence of Discoaster bifax has been used to firmly assign sediments to Zone NP16. The sedimentary interval between the HO of Chiasmolithus gladius and the LO of D. bifax is assigned to undifferentiated Zones NP15NP16.

\section{STRATIGRAPHIC CORRELATIONS}

There is good agreement between the stratigraphic subdivisions based on calcareous nannofossils and planktonic foraminifers. However, because the calcareous nannofossils provide firm biozonal subdivisions unlike the planktonic foraminifers as discussed above, the correlations between Holes 903C and 904A (Fig. 1) are based on calcareous nannofossil stratigraphy alone. "NP" zones refer to the calcareous nannofossil zonation of Martini (1971) and "P" zones refer to the planktonic foraminiferal zonation of Berggren and Miller (1988). Description of Paleogene subzones of Martini's calcareous nannofossil zones can be found in Aubry (1991). Also, Martini's (1971) Zones NP19 and NP20 are not distinguished, following Martini (1976) and Martini and Müller (1986).

Upper lower or lower middle Eocene chalks were recovered from Hole 904A only. They are assigned to Subzone NP14a (see Aubry, 1991 , for the definition of the subzone) and questionably to planktonic foraminifer Zone P9.

Middle middle Eocene chalks were recovered from Hole 903C, where they are assigned to Zone NP16 and to Zones P13 and P14; and from Hole 904A, where they are assigned to calcareous nannofossil Subzone NP15b (see Aubry, 1991, for the definition of the subzone), undifferentiated Zones NP15-NP16, Zone NP16, and Zone NP17, and to planktonic foraminiferal undifferentiated Zones P9-P10, Zone P11, Zone P12, and undifferentiated Zones P13-P14.

Upper Eocene chalks were recovered from the four holes, but lower upper Eocene chalks (Zone NP18) were recovered only from Holes $903 \mathrm{C}$ and $904 \mathrm{~A}$, where they constitute a very thin interval. The bulk of the upper Eocene chalks belongs to Zones NP19-20. The sequential highest occurrences of Discoaster saipanensis, D. barbadiensis, and Reticulofenestra reticulata below the Eocene/Oligocene contact indicates that the upper part of Zones NP19-20 is well represented. The absence of sediments assignable to Zone NP21 indicates that uppermost Eocene sediments were not recovered, in agreement with the planktonic foraminiferal stratigraphy. The ranges of Hantkenina alabamensis (Holes 902D, 904A), Pseudohastigerina micra (Holes 902D, 903C, 904A), Subbotina eocaena (Holes 902D, 903C, 904A), S. tripartita (Hole 903C), S. yeguaensis (Holes 902D, 903C), Turborotalia alabamensis (Hole 904A), T. cerroazulensis cerroazulensis (Hole 902D), T. cerroazulensis cocoaensis (Hole 903C), and T. increbescens (Hole 903C) are truncated at the Eocene/Oligocene unconformable contact.

The upper part of the upper Eocene chalks in Hole 904A yields a normal polarity that is tentatively interpreted as representing Chron C15n in Mountain, Miller, Blum, et al. (1994) and in Van Fossen and Urbat (this volume). Microfossil biostratigraphy does not support this interpretation. Indirect magnetobiostratigraphic correlations indicate that the chalks immediately below the Eocene/Oligocene contact should yield a reversed polarity, representing Chron C13r (see Berggren et al., 1995). Considering the weakness of the magnetic signal of the Eocene chalks, normal polarity is more likely the result of remagnetization rather than a genuine signal. Likewise, the normal-polarity interval in Core 150-902D-72X may or may not be reliable. It is located farther down in Zones NP19-20 than it is in Hole 904A and could represent Chron $\mathrm{C} 15 \mathrm{n}$. Yet, without knowledge of the stratigraphic extent of this normal polarity interval, it is not possible to identify it.

\section{DISCUSSION AND CONCLUSION}

Microfossil stratigraphy - in particular, calcareous nannofossil stratigraphy - allows the delineation of several unconformities. The oldest occurs in Core 150-904A-60X, but the contact between the upper lower or lower middle (Subzone NP14a) and middle (Subzone NP15b) Eocene chalks was not recovered. Unconformable contacts 


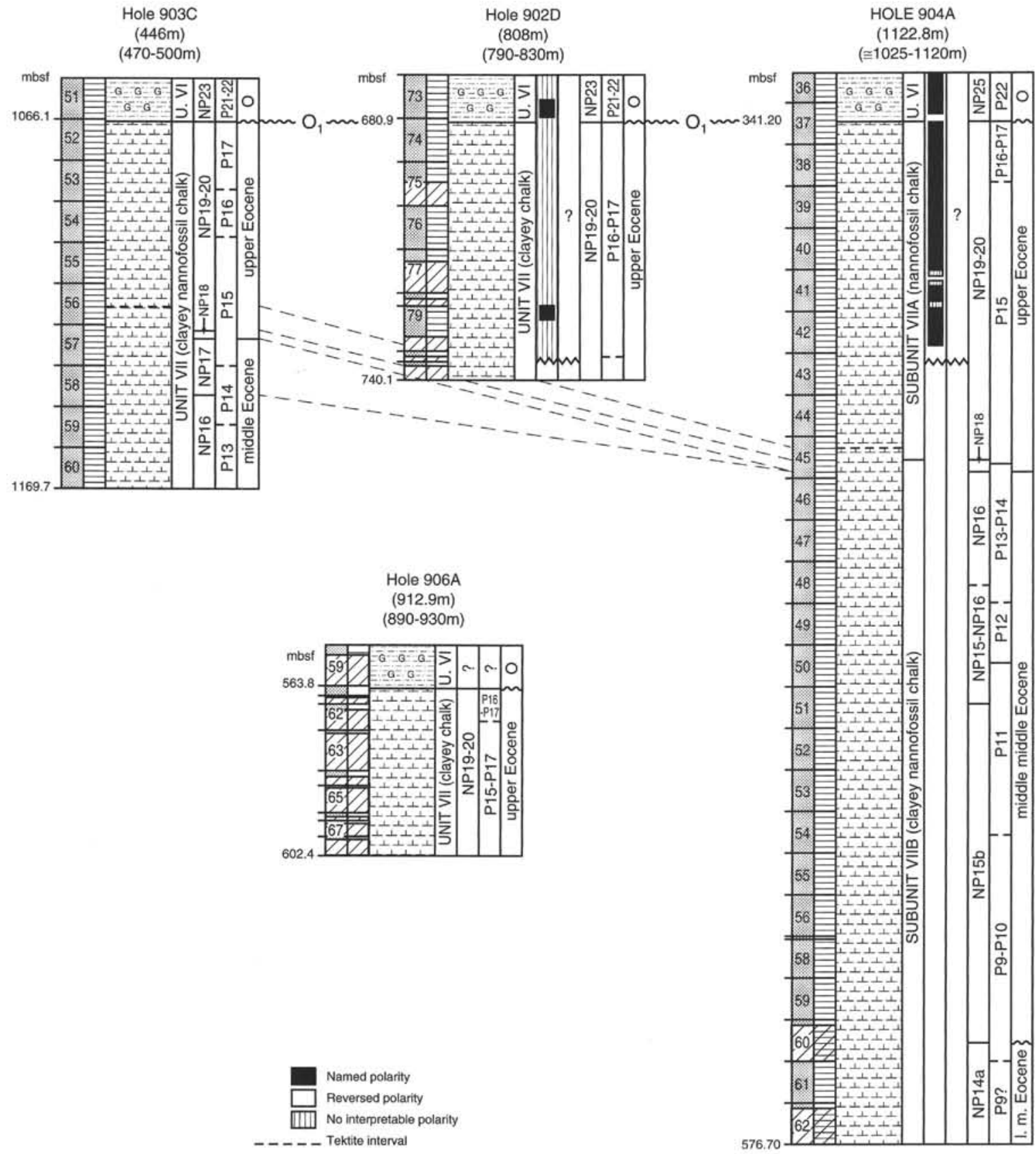

Figure 1. Stratigraphic correlations of the upper Eocene sections recovered from Holes 902D, 903C, 904A, and 906A on the continental slope of the New Jersey Margin (Leg 150). Columns represent, from left to right, cores, sections, lithology, lithologic units, magnetic polarity and interpretation (Hole 902D and 904A), calcareous nannofossil zonal subdivisions, planktonic foraminiferal zonal subdivisions, and series. Backstripped paleodepth (see Katz and Miller, this volume) is given below present water depth for each hole. The upper Eocene section in Hole 906A is correlatable with that in the other holes, but the hole was not drilled along the same transect as the other three holes. Oblique hatched pattern in core/section columns indicates intervals of no recovery. Bold dashed line in Cores 150-903C-56X and 904A-45X indicates position of the tektites (Hole 904A) or level thought to be equivalent (Hole 903C). Jagged lines in magnetostratigraphic columns (Holes 902D and 904A) indicate levels below which there was no magnetic signal.

in the same interval have been described from other sections on the New Jersey Margin, at such offshore sites as DSDP Sites 605, 612, and 613 (Olsson and Wise, 1987a, 1987b; Poag and Low, 1987; Aubry, 1991) and onshore sites such as the AGCS \#4 well (Miller et al., 1990; Aubry, 1991) and the Island Beach well (Miller et al., 1994).

The next obvious unconformity separates either middle (Zone NP16) from upper Eocene (Zone NP18) chalks or middle Eocene (Zone NP16) from middle Eocene (Zone NP17) chalks. This is seen in Holes 904A and 903C, respectively. The unconformable NP16/ NP17 zonal contact is well marked by the reworking of Zone NP16 nannofossil taxa (e.g., Sphenolithus furcatolithoides) into Zone NP17. It is possible that Zones NP17 and NP18 are unconformable in Hole $903 \mathrm{C}$, but there is no direct evidence that this is the case. In DSDP Hole 612 and in onshore wells, middle Eocene (Zone NP16) chalks are also directly unconformable with upper Eocene (Zones NP19-20) chalks as reliably dated by calcareous nannofossil stratig- 
raphy (Poag and Aubry, 1995). It appears that this is another widespread unconformity on the New Jersey Margin.

Insufficient biostratigraphic resolution and lack of magnetostratigraphy prevent the dating through integrated magnetobiostratigraphy (except in very broad terms) of the unconformable surfaces discussed above. However, it is possible to date rather precisely the age of the upper surface of the upper Eocene sequence using ages of the LADs of a number of planktonic microfossils, as estimated in Berggren et al. (1995). This surface is obviously older than the LAD of the latest Eocene planktonic foraminifer Hantkenina spp. (estimated age = 33.7 Ma in Berggren et al., 1995), the LAD of Turborotalia cerroazulensis (estimated age $=33.8 \mathrm{Ma}$ ), and the LAD of D. saipanensis (estimated age $=34.2 \mathrm{Ma}$ ), but younger than the LAD of $D$. barbadiensis (estimated age $=34.3 \mathrm{Ma}$ ). The age of the upper surface of the Eocene sequence is thus estimated at $34.25 \mathrm{Ma}$. This implies that the maximum age of the seismic reflector $\mathrm{O} 1$, as expressed along the New Jersey transect (Miller and Mountain, 1994), is $\sim 34.25 \mathrm{Ma}$.

Finally, an upper Eocene tektite-rich interval, correlative with that recovered from DSDP Site 612, was recovered from Hole 904A.

\section{ACKNOWLEDGMENTS}

We thank J.E. Hazel, M. Katz, C.W. Poag, and R. Wathen for reviewing and editing the manuscript. This is ISEM contribution no. 96000 .

\section{REFERENCES}

Aubry, M.-P., 1991. Sequence stratigraphy: eustasy or tectonic imprint? J. Geophys. Res., 96:6641-6679.

1992. Late Paleogene calcareous nannoplankton evolution: a tale of climatic deterioration. In Prothero, D.R., and Berggren, W.A. (Eds.), Eocene-Oligocene Climatic and Biotic Evolution: Princeton, NJ (Princeton Univ. Press), 272-309.

Berggren, W.A., Kent, D.V., Swisher, C.C., II, and Aubry, M.-P., 1995. A revised Cenozoic geochronology and chronostratigraphy. In Berggren, W.A., Kent, D.V., and Hardenbol, J. (Eds.), Geochronology, Time Scales, and Global Stratigraphic Correlations: A Unified Temporal Framework for an Historical Geology. Spec. Publ.-Soc. Econ. Paleontol. Mineral., 54:129-212.

Berggren, W.A., and Miller, K.G., 1988. Paleogene tropical planktonic foraminiferal biostratigraphy and magnetobiochronology. Micropaleontology, 34:362-380.

Martini, E., 1971. Standard Tertiary and Quaternary calcareous nannoplankton zonation. In Farinacci, A. (Ed.), Proc. 2nd Int. Conf. Planktonic Microfossils Roma: Rome (Ed. Tecnosci.), 2:739-785.

1976. Cretaceous to Recent calcareous nannoplankton from the Central Pacific Ocean (DSDP Leg 33). In Schlanger, S.O., Jackson, E.D., et al., Init. Repts. DSDP, 33: Washington (U.S. Govt. Printing Office), $383-423$.

Martini, E., and Müller, C., 1986. Current Tertiary and Quaternary calcareous nannoplankton stratigraphy and correlations. Newsl. Stratigr., 16:99112.

Miller, K.G., et al., 1994. Proc. ODP, Init. Repts., 150X: College Station, TX (Ocean Drilling Program).

Miller, K.G., Kent, D.V., Brower, A.N., Bybell, L.M., Feigenson, M.D., Olsson, R.K., and Poore, R.Z., 1990. Eocene-Oligocene sea-level changes on the New Jersey coastal plain linked to the deep-sea record. Geol. Soc. Am. Bull., 102:331-339.

Miller, K.G., and Mountain, G.S., 1994. Global sea-level change and the New Jersey margin. In Mountain, G.S., Miller, K.G., Blum, P., et al., Proc. ODP, Init. Repts., 150: College Station, TX (Ocean Drilling Program), 11-20.

Mountain, G.S., Miller, K.G., Blum, P., et al., 1994. Proc. ODP, Init. Repts., 150: College Station, TX (Ocean Drilling Program).

Olsson, R.K., and Wise, S.W., 1987a. Upper Maestrichtian to middle Eocene stratigraphy of the New Jersey slope and coastal plain. In van Hinte, J.E., Wise, S.W., Jr., et al., Init. Repts. DSDP, 93 (Pt. 2): Washington (U.S. Govt. Printing Office), 1343-1365.

, 1987b. Upper Paleocene to middle Eocene depositional sequences and hiatuses in the New Jersey Atlantic Margin. In Ross, C., and Haman, D. (Eds.), Timing and Depositional History of Eustatic Sequences: Constraints on Seismic Stratigraphy. Spec. Publ. Cushman Found. Foraminiferal Res., 24:99-112.

Poag, C.W., and Aubry, M.-P., 1995. Upper Eocene impactites of the U.S. coast: depositional origins, biostratigraphic framework, and correlation. Palaios, 10:16-43.

Poag, C.W., and Low, D., 1987. The New Jersey transect: stratigraphic framework and depositional history of a sediment-rich passive margin. In Poag, C.W., Watts, A.B., et al., Init. Repts. DSDP, 95: Washington (U.S. Govt. Printing Office), 763-817.

Shipboard Scientific Party, 1987. Site 612. In Poag, C.W., Watts, A.B., et al., Init. Repts. DSDP, 95: Washington (U.S. Govt. Printing Office), 31-153.

, 1994a. Site 902. In Mountain, G.S., Miller, K.G., Blum, P., et al., Proc. ODP, Init. Repts., 150: College Station, TX (Ocean Drilling Program), 63-127.

1994b. Site 903. In Mountain, G.S., Miller, K.G., Blum, P., et al., Proc, ODP, Init. Repts., 150: College Station, TX (Ocean Drilling Program), 129-205.

, 1994c. Site 904. In Mountain, G.S., Miller, K.G., Blum, P., et al., Proc. ODP, Init. Repts., 150: College Station, TX (Ocean Drilling Program), 207-253.

, 1994d. Site 906. In Mountain, G.S., Miller, K.G., Blum, P., et al., Proc. ODP, Init. Repts., 150: College Station, TX (Ocean Drilling Program), 309-357.

Date of initial receipt: 18 September 1995

Date of acceptance: 23 February 1996

Ms 150SR-037 